\title{
24
}

PROJECT MUSE

Queer Objects: Gendered Interests and Distant Things in

Jeanette Winterson's Oranges Are Not the Only Fruit

Jesse Bordwin

Contemporary Literature, Volume 60, Number 2, Summer 2019, pp. 227-252

(Article)

Published by University of Wisconsin Press

$\Rightarrow$ For additional information about this article

https://muse.jhu.edu/article/757961 


\section{JESSE BORDWIN \\ Queer Objects: Gendered Interests and Distant Things in Jeanette Winterson's Oranges Are Not the Only Fruit}

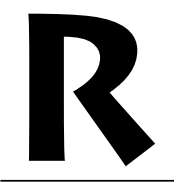

ecent materialist literary criticism has freed the fictional object from its old duties_-simulating verisimilitude or standing in for capital and commodity-and illuminated the structural, affective, and aesthetic roles of things in literature. But these newly visible objects are not easily interpolated into existing critical frameworks because they are neither properly material and independent from subjective description, perception, and concern nor entirely comfortable in the humanistic fabric of the novel. One practice well suited to describe such things is new feminist materialism, an umbrella phrase for a set of practices that share the goals of moving feminist theory beyond the impasse of the linguistic turn and reconciling the insights of constructionism with the thingness of the world. By balancing language and matter, new feminist materialism seems well situated to describe objects embedded in the aesthetic world of the novel. ${ }^{1}$ Yet a lingering

1. If new feminist materialism is particularly evocative for literary scholars because of its insistence on "the deconstruction of the material/discursive dichotomy that retains both elements without privileging either," we should also recognize the critical practices that proved foundational for new feminist materialism but fall outside the purview of this essay (Alaimo and Hekman 6). This includes the work of feminist and queer phenomenologists like Karen Barad and Sara Ahmed, as well as that of ecofeminists. Ecofeminist literary critics particularly attend to how texts structure the relationships between human characters and literary worlds and show how literature performs the displacement of the human subject-or elevation of nonhuman subjects-without jettisoning human political attachments. Wendy Lee-Lampshire uses Wittgenstein to show how adopting a language of psychology to describe ostensibly nonthinking objects or "treating something as a subject is informative" (416). In doing so, "we may conceive the application of psychological terms such as subject or $I$ as an act of taking responsi- 
political and ontological unease around the relationship between women and things-and the consequent threat that a turn to objects necessitates a turn away from the subject-keeps new feminist materialism focused on the materiality of the body and indifferent to those things that conduct their lives beyond our ken. But as I show through a reading of Jeanette Winterson's Oranges Are Not the Only Fruit, objects are not antagonistic to gendered interests; they advance them. Winterson recognizes the inherent queerness of literary objects-as both language and matter and as strangely dependent on human amanuenses even as they insist on their own existence-and how such objects' ambivalence allows the lesbian artist to thrive. The things that populate the novel—an uncanny pebble, a slice of fruitcake inhabited by a miniature township, mismatched felt Bible characters, a piece of whalebone-and their strange distance and closeness to the young queer protagonist model forms of equity and coexistence, radically extend liveliness into the world and onto non- and subhuman Others, recover spaces that have long been occupied, and provide a refuge from chauvinist ideology. The novel's vision of a material world that is neither subsumed by nor completely withdrawn from the subject makes the bildungs plot possible even in the face of violent social strictures and models how materialist critics might balance gendered interests with the quiet clamor of distant objects.

The balance of commitments that I find useful in new feminist materialism is what drives the skepticism of other materialists. Object-oriented ontologist ${ }^{2}$ Ian Bogost writes: "The big question is how critical approaches like feminism (and political economy, and

bility for the evolving and complex world described by such an application (Lee-Lampshire 421). Gretchen T. Legler uses a similar concept, that of the "postmodern pastoral," which is "a posthumanist construction of human relationships with nature that makes more sense in a postmodern world; a vision that is informed by ecological and feminist theories, and one that images human/nature relationships as 'conversations' between knowing subjects" (229). Patrick D. Murphy shows how an ecofeminist literary criticism could "more productively imagine responsible human behavior through working out the implications of a theory of volitional interdependence among human and nonhuman alike" (150). Their work is necessary for understanding the particular ability of literary texts to reshape ontological and political structures to provide more habitable worlds, especially for female and queer subjects.

2. Object-oriented ontology is a metaphysics that rejects the Kantian correlation between thought and being. It maintains that there is a world of objects that exist inde- 
psychoanalysis, and many others) will deal with OOO's charge to extend beyond human interests." Or as Paul Reid-Bowen puts it to Bogost, "The main problem for a feminist version of OOO will probably remain the focus on the human" (Bogost, "Object-Oriented Feminism"). We should be suspicious of this phrasing, which sets the too-human attachments of new feminist materialism against OOO's cool neutrality. ${ }^{3}$ Object-oriented ontology's displacement of the subject, which might appear egalitarian or at least doctrinally impartial, has destructive methodological and institutional consequences. ${ }^{4}$ The abnegation of the subject, which seems to occur more broadly in response to claims by outsider groups asserting their subjectivity, is a political move, one that makes the turn to objects seem neutral or natural while reproducing its own agenda and excluding others. ${ }^{5}$

Katherine Behar opens the collection Object-Oriented Feminism with an anecdote illustrating what kinds of subjects disappear under OOO. Bogost designed an "image toy," a computer program that displayed random photographs from Flickr that users tagged as "object," "thing," or "stuff." The idea was that "[i]ts surprising mismatches express a wondrously unpredictable and nonanthropocentric 'universe of things"' (Behar 2). But then, according to Bogost,

pendent of human cognition and perception and that are not ontologically exhausted by their relations with humans or other things.

3. We should also be suspicious of OOO's claim of egalitarianism: it is not enough to identify a feminist politics by "affirming that it undoes dualisms and is therefore feminist 'by nature'" (Hinton and Van der Tuin 1).

4. Disciplinary permutations of the material turn often exclude female practitioners and feminist writing. Sara Ahmed, one of the critics who has most forcefully combatted the erasure of women in materialist fields and metaphysics, tweeting as @feministkill joy, writes: "Interesting that: the post-human seems as white as the human," and, "why not wonder why the agency of the non-human has come to matter when we are dealing with the costs of human agency!"

5. David Simpson argues that the crisis of the subject is really another way of reinforcing that very category, whereby "the avowed instability of the subject is its very mechanism of self-insurance, its strategy for holding on to its gains and privileges, so that the anglophone construction of crisis becomes itself ideological, a pathos of imagined dispossession that signals the exact opposite" (9). I build on Simpson by way of Gayatri Chakravorty Spivak and argue that this play of insecurity is strongly gendered and racialized, for where confusion and unknowing so often work to the advantage of the white male subject, the same symptoms are conventionally deployed to discredit nonwhite and nonmale subjects. 
"a (female) colleague had showed the site to her (female) dean-at a women's college, no less," and the image that appeared at that moment was of a Playboy Bunny (Bogost, Alien Phenomenology 98). In response to fears that viewers would see "object-oriented" as "objectifying," Bogost changed the algorithm to bypass certain tags: "options.Tags = '(object OR thing OR stuff) AND NOT (sexy OR woman OR girl)"' (Bogost, Alien Phenomenology 99). One problem is solved, but another is inaugurated; Playboy Bunnies-and women more broadly-are erased from a universe of things that still includes men-sexy and not. Too often the turn to objects shores up a particular kind of white male subject, evinced in object-oriented criticism's moral and imaginative failure to take into account how other kinds of subjectivity have always been unstable or contested and how certain subjects have always been made object-like.

Bogost's discomfort here stems from the slippage between object and objectification, an inheritance that motivates new feminist materialism while producing its lacunae. There are good reasons for feminist materialists to be suspicious of things as such: privileging objects and objectivity has led to the erasure of certain kinds of subjects and subjectivity, consolidating power in regimes of knowledge that traditionally exclude women. ${ }^{6}$ In what I understand to be a response to this history, new feminist materialism has strategically bypassed the object qua object in favor of the body. Stacy Alaimo and Susan Hekman begin their important collection Material Feminisms by asserting that "[w]omen have bodies," and that "[w]e need a way to talk about these bodies and the materiality they inhabit" (4). Introducing a special edition of Women published in 2014 titled "Feminist Matters: The Politics of New Materialism," Peta Hinton and Iris van der Tuin write that "culture is manifestly biological at the most intricate, molecular level," which "makes feminist political

6. Rita Felski writes, "Feminism has its own complicated relationship to things, colored by a perception that women have often been treated as akin to objects. Objecthood was something to be disavowed, even repudiated, a pitfall rather than a promise. Feminists have been far more invested in thrashing out questions of subjectivity as they relate to women ... than in investigating the mysteries of the object" (185). She builds on an older critique that accounts of "objects can seem to be either appropriations of a fixed and determined world reduced to resource for instrumentalist projects of destructive Western societies, or they can be seen as masks for interests, usually dominating interests" (Haraway 591). 
practices and interventions themselves expressly, and irrevocably, material, and biologically reconfigured" (5). The purpose of new feminist materialism, writes Victoria Pitts-Taylor, is to "take up the 'real,' fleshly body, nature, and ontology" (9). The object of new feminist materialism, in other words, is also always a subject; but if the fleshy, sensual body's emergence as originary object represents a politically necessary recovery, it threatens a kind of solipsism, overshadowing the things that are less like us.

Insofar as this is a problem, it is not the same one identified by object-oriented ontology; rather than see new feminist materialism as too bound up in the human, I would have it extend its gendered interests out into the world of things that exist beyond the body. I disagree with the assumption in Bogost's question-of "how critical approaches like feminism ... will deal with OOO's charge to extend beyond human interests" - and wonder why new feminist materialism must renounce these attachments when they are perhaps especially equipped to attend to the object world without erroneously claiming to bypass human-and gendered-interests. These very commitments make new feminist materialism a better fit for literary criticism than object-oriented ontology. To my mind, the latter cannot adequately describe concepts like authorship, readership, taste, fiction, imagination, form, and aesthetics-certainly not in ways that accord with everyday reading practices-and its antianthropocentrism is ill-suited for the novel, a genre that does privilege the human subject. At the same time, if the matter of new feminist materialism cannot point beyond our own thingness, such a practice will be unable to recognize the objects that hum and scuttle and squat beyond the body but within the scope of human perception, knowledge, imagination, storytelling, and meaning making. ${ }^{7}$

7. It is worth noting here that object-oriented feminism-which occupies the space somewhere between new feminist materialism and $\mathrm{OOO}-$ models itself as a practice that springs from this tension: for Behar, "objectification, utilitarianism, and instrumentalization are presences that haunt $\mathrm{OOO}$, and are among the very questions at the heart of objectoriented feminism" (20). But OOF has come under attack "from feminist scholars who see OOF as appropriating feminist intellectual history and energy, leaving in its wake an enervated politics" (Bordwin 390). Rebekah Sheldon suggests that "OOO has been so provocative for feminist theorists because of its canny and knowing usurpation of the energies of feminist thought and its relegation of that history to footnotes within its own autobiography." Rather than conclude, as Sheldon does, that there can be "no such 
Where new feminist materialism coheres around the body, Jeanette Winterson imagines an ecosystem that extends far into the material world as the space where feminist life and art unfold. By refusing to collapse objects into the body or rend them from the political concerns of the subject, Winterson creates a system of selves and things integral to a feminist metaphysics, in which even those objects whose relationships with subjects are characterized by distance or unknowing can take part in a feminist politics.

In retrospect, Winterson seems both beneficiary and casualty of the intellectual and critical milieu from which she emerged. If her experiments with subverting identity and narrative in the age of poststructuralism contributed to her meteoric rise, the terms of her reception in the 1980s and early 1990s continue to dictate the direction of Winterson scholarship in ways that have, until recently, proved limiting. ${ }^{8}$ Winterson has long rejected the mantle of postmodernism-she identifies as an inheritor of the modernist project (Pykett 53) - and a recent wave of criticism has reinstated what was lost in the emphasis on discourse: the rich materiality of her aesthetic worlds. This scholarship, much of which centers around Written on the Body (1992) and The PowerBook (2000), does not jettison Winterson's frequent emphasis on narrative voice, language play, gender bending, genre mashing, and the like. Instead, it joins questions of language, power, and meaning to a consideration of queer, female, or ungendered bodies. This coalescing echoes that in new feminist materialism, as the body becomes the object par excellence.

When these interpretations are persuasive, it is because Winterson clearly does see the body as a kind of ecstatic nexus where the institutions that partition us from one another and the natural world collapse and give way to a tangle of matter, meaning, history, and

thing as an object-oriented feminism," one way forward from here is to acknowledge how there have long been object-oriented feminisms.

8. This is to reaffirm Merja Makinen's claim that "The main focus of the reception of Winterson's novels has been twofold: the discussion in relation to her as a lesbian writer and in relation to her as a postmodern writer" (2), and Lyn Pykett's charge that "Academic criticism, which Winterson so disparages, seems to place her self-consciously and self-proclaimed experimental fictions (when it notices them at all) in the boxes labelled 'lesbian fiction' or 'postmodernist fiction'” (53). 
language. ${ }^{9}$ What this narrative of union misses is the importance of a material world beyond the body and the political and aesthetic value of the distance between subject and object. Certainly the protagonist of Oranges Are Not the Only Fruit searches for a romantic love that will obliterate the space between her and the world: "I want someone who will destroy and be destroyed by me," she declares, as she recalls the strictures of her childhood (174). But that romantic dissolution of the self never happens in the novel; to survive, the queer subject must sever her ties to the hostile world around her. Forms of connection and consolation must be found elsewhere, like in the objects scattered throughout the novel that produce a different set of artistic and affective possibilities for the beleaguered subject. Matter involves much more than bodies.

Published in 1985, Oranges Are Not the Only Fruit was Winterson's first novel; with the help of the widely seen BBC adaptation that followed, it quickly launched her career. Closely modeled on the author's own life, it follows a girl named Jeanette who grows up with her intensely religious adoptive mother in an industrial town in postwar northern England. Constrained by her increasingly suffocating Pentecostal community, Jeanette spends much of her time dreaming up fantasies, spinning tales that transport her from her constrictive reality. Storytelling helps her cope with the world, but after a series of attempts to heal Jeanette of her lesbianism culminate in a violent exorcism, Jeanette leaves for a new life in London. In many ways, the narrative is a classic bildungs- or künstlerroman, but it is notable for how sharply attenuated the possibilities are for Jeanette's social growth and identity formation. Jeanette is kept out

9. "Winterson weds the act of storytelling to the body," Jennifer A. Smith writes, "specifically to the touching of bodies and the transformative energy that such contact creates, thus adding the body's variability to the already established fluidity of gender, sexuality, subjectivity, language, and love" (418). Madelyn Detloff turns to DNA to move away from the "old myth of transcendence that valorizes mind over matter, the spirit over the body" (152), toward a future where the body is both substance and the code for its own substance, rendering it "simultaneously actual and virtual, physical and temporal" (154). For Tyler Bradway, Winterson's characters "move toward an exuberant becoming with the other that undermines the subject's patriarchal transcendence of corporeality and embraces their body's irreducibly queer relationality" (146). Leigh Gilmore explores how Winterson represents material bodies that are always "caught up in competing systems of meaning" (125). 
of public school for as long as legally possible, restricted to interacting only with her mother's church friends, and given limited access to secular reading material. ${ }^{10}$ The problem is societal-Jeanette's lesbianism precludes her from proper socialization-but also, as Laurel Bollinger suggests, generic: the bildungsroman is traditionally a story of male development in which boys eventually leave home, whereas girls must not "destroy the familial relationship" (363). Given the circumscription of Jeanette's environment and narrative options, where is the potential for growth? Under these circumstances, Jeanette forges an identity in dialogue with objects. Coming of age, which for Jeanette means coming of age as a queer woman, becomes an object-oriented practice.

To start creating a hospitable environment, Jeanette must reorient the matter and meaning of the things around her, trapped as she is among people and objects that are shaped by and in turn promulgate repressive discourses. The scorn she receives from male religious figures is tied to their Pentecostalism and its attitude toward the material and natural worlds, which replicate misogyny, homophobia, and racism in and through objects. Oranges Are Not the Only Fruit is filled with religious kitsch, objects that have no artistic or material value but are hollowed out to produce only one signification, working to "evoke unambiguously, dispelling ambivalence and abstraction" (Olalquiaga 41). When celebrating Christmas, Jeanette looks on as her mother unwraps a present sent to her from Pastor Spratt from his mission work in Africa: "It was an elephant's foot, with a hinged top. She hesitated a moment, then flung back the lid. It was an elephant's foot Promise Box; two layers of little scrolls, all rolled up, each with a promise from the Word. My mother had tears in her eyes, as she put it carefully on top of the sideboard" (181). The foot, eviscerated to make space for the word of God, is also disemboweled rhetorically: the noun phrase "an elephant's foot" transforms into an adjectival one, "an elephant's foot Promise Box." The thing itself disappears; it is a medium, a way to get to something

10. This is another autobiographical detail. Winterson has written: "My parents owned six books between them. Two of those were Bibles and the third was a concordance to the Old and New Testaments. The fourth was The House at Pooh Corner. The fifth, The Chatterbox Annual 1923 and the sixth, Malory's Morte d'Arthur" ("Art and Life" 153). 
else that isn't there. That the promise box was once part of a living creature only amplifies the sense that there is something perverse in this evacuation of objecthood. The language of Christian orthodoxy allows characters "to exploit nature in a mood of indifference to the feelings of natural objects" and leads to the proliferation of religious and colonial kitsch throughout the novel (White 1205). ${ }^{11}$ Surrounded by objects that have been forced into telling the same story of domination, remaking the world becomes Jeanette's ethical and creative imperative.

Jeanette reclaims the narrative potential of objects by short-circuiting the logic of kitsch-or, more broadly, the icon or symbolwhich creates room for new stories. For the loop between object and orientation to function smoothly, the symbol must be neutered of features that interrupt the flow of meaning. When Jeanette is told that "God's in everything" (30) and "everything in the natural world was a symbol of the Great Struggle between good and evil" (16), it oversaturates objects with a single meaning that points in a single direction. But Jeanette, flirting with apostasy, reasserts the immanence of objects. Consider how she describes the painting of Christ that her family keeps in the kitchen:

It was a watercolour about nine inches square, painted by Pastor Spratt for my mother, before he left with his Glory Crusade for Wigan and Africa.

It was called "The Lord Feeding the Birds" and my mother put it over the oven because she spent most of her time there, making things for the faithful. It was a bit battered now, and the Lord had a blob of egg on one foot, but we didn't like to touch it in case the paint came off too.

The painting is another example of religious kitsch, the materiality of which remains invisible as long as it continues to lead the viewer

11. The promise box is one example of many: Jeanette's mother keeps a picture by her bed of Pastor Spratt "surrounded by black men with spears" (8), and it is "Pastor Spratt's crocodile nutcracker"- a souvenir from Africa- "[that] took pride of place on the mantelpiece" (98). Even non-Christian objects become converted, as it were, under Pastor Spratt's watch: he celebrates his "ten thousandth convert" by touring Europe with "his collection of weapons, amulets, idols and primitive methods of contraception. The exhibition was called 'Saved by Grace Alone"' (35). These artifacts are "saved" from their original context when relocated to another. Pastor Spratt is absent throughout the novel, but his presence is reinforced in the system of objects and signs that refer back to him. 
to the intended signified. Here, Jeanette's attention snags on the blob of egg's interaction with the paint, pausing on the object and refusing to be transported elsewhere. The splattered icon becomes (ahem) scrambled, which allows for a moment of object-seeing in the wake of transcendence's failure.

Recognizing the materiality of religious discourse, how it coalesces in her environment or, in other words, how it matters, Jeanette can manipulate these manifestations of ideology and remake her world. Early in the novel, Jeanette plays with the odds and ends she finds in a church classroom:

There was some Fuzzy Felt to make Bible scenes with, and I was just beginning to enjoy a rewrite of Daniel in the lions' den when Pastor Finch appeared. I put my hands into my pockets and looked at the lino.

"Little girl," he began, then he caught sight of the Fuzzy Felt.

"What's that?"

“Daniel," I answered.

"But that's not right," he said, aghast. "Don't you know that Daniel escaped? In your picture the lions are swallowing him."

"I'm sorry," I replied, putting on my best, blessed face. "I wanted to do Jonah and the whale, but they don't do whales in Fuzzy Felt. I'm pretending those lions are whales."

"You said it was Daniel." He was suspicious.

"I got mixed up."

He smiled. "Let's put it right, shall we?" And he carefully rearranged the lions in one corner, and Daniel in the other. "What about Nebuchadnezzar? Let's do the Astonishment at Dawn scene next." He started to root through the Fuzzy Felt, looking for a king.

"Hopeless," I thought, Susan Green was sick on the tableau of the three Wise Men at Christmas, and you only get three kings to a box.

As other scholars have noted, Jeanette's revisionist mixing of biblical stories undermines male power and religious self-seriousness. What draws my attention to this and similar scenes in the novel is the detail Jeanette pays to the particular material conditions of her handicraft. ${ }^{12}$ She treats biblical stories like she does religious

12. In another example, Jeanette plays with a collage of Noah's ark, getting "delight [from] a detachable chimpanzee, made out of a Brillo pad; at the end of my visit [I played] with it for five minutes. I had all kinds of variations, but usually I drowned it" 
kitsch: although they are meant to point to an established meaning or moral, by focusing on the materiality of storytelling, Jeanette rearranges the building blocks to create new signification. She evades the pastor's accusation of heterodoxy by blaming the lack of whales on the makers of Fuzzy Felt, and she knows the pastor will not be able to re-create the scene of Nebuchadnezzar's astonishment because she has insight into the history of these objects. Her understanding of the material world is inaccessible to the pastor because the objects do not matter to him as objects. For the pastor, the Fuzzy Felt figures are conduits to ideology; for Jeanette, they are the refuge from it. Objects encourage the pastor's thoughts to fly past the physical toward the heavenly, while Jeanette's remain below, fixed on the material. By recognizing ideology's materiality and its ability to sculpt the subject's relationship to the world of things, Jeanette revises what might otherwise seem intangible and thus unassailable. $^{13}$

Jeanette repeatedly turns to objects when she has no control over the language available to her. Language is slippery; it can be used against her. At one point in the novel she hides in the library; there "I felt better, words you could trust and look at till you understood them, they couldn't change half way through a sentence" (72-73). Winterson distinguishes between spoken discourse and written language, where the latter's fixity, a product of its materiality, is much safer for Jeanette. This is not to suggest that Jeanette is unable to wield language in powerful ways: she identifies as a skilled sermonizer. "Some of us could preach," Jeanette notes of the women in her congregation, "and quite plainly, in my case, the church was full

(22-23). Jeanette engages in such material revisions throughout the novel and she does so skillfully, referring to her handicrafts, from a religious-themed needlepoint (45) to an eggshell diorama (49), as "masterpieces." Whether this is an accurate portrayal of her talents or not, Jeanette's appreciation of her own excellence underscores art's function.

13. This missionary zeal backfires on occasion. One of the objects Pastor Spratt sends the family is a missionary map: "On the front were all the countries and on the back a number chart that told you about Tribes and their Peculiarities. My favourite was Number 16, The Buzule of Carpathian. They believed that if a mouse found your hair clippings and built a nest with them you got a headache. If the nest was big enough, you might go mad. As far as I knew no missionary had yet visited them" (2). The intent of this document is to make alien other worldviews, but instead, it seems to give Jeanette an understanding that outside her community, people have radically different relationships between subjects and objects. 
because of it" (135-36). Yet the descriptions she provides of her own preaching are notably abbreviated:

Our first meeting that night was a great success. I was down to preach, and as usual a great number found the Lord.

"She's lost none of her gifts, has she?" May grinned at my mother.

There is a hole where we expect to find the content of her sermon. We never see a single line of Jeanette's proselytism in Oranges Are Not the Only Fruit, a glaring omission given the importance she puts on speaking in the church. As when she emphasizes the materiality of religious icons, Winterson seems to proceed by misdirection, focusing on what seems like the wrong thing. I connect the absence of the sermon to the eventual decision made by the pastor that women can no longer preach, a conclusion he justifies by correlating Jeanette's lesbianism to the congregation's decision "allowing women power in the church" (135). "The message," as even Jeanette's mother asserts, "belonged to the men" (136). Jeanette's preemptive excision of her sermons from the text is a form of self-protection: there is a liability to staking her identity, especially as a queer woman, in a language that can so easily be turned against her. The speech act must be coupled with language's thingness to give Jeanette purchase on what might otherwise be taken from her.

Playing with objects and language, Jeanette becomes a bricoleur, and her art recombines the elements she has at hand to produce new meaning. We should read these passages as descriptions of Winterson's own labor of crafting the novel. As is frequently true, an attention to objects in novels is also a way of understanding the work of the novelist and the novel as a material creation. This is not simply to say that Jeanette's feminist art mirrors Winterson's, as other critics have argued. I mean to highlight the political importance of objects and novelistic language's materiality to this narrative of feminist bricolage. The connection between the sanctuary offered by literary objects and that posed by acts of making and remaking takes a cue from Susan Fraiman's work on "shelter writing," in which she shows how a certain narrative mode concerning the domestic "may often go hand in hand with novelistic self-referentiality" (42). Just as Fraiman proposes that "descriptions 
of characters making and keeping house may offer writers a store of images for their own barely waged work of conjuring and furnishing the spaces in which people dwell" (43), I propose that certain representations of women engaging the object world in creative and revisionary ways offer feminist writers models for representing the material processes of their own writing. By coding the creative process as material—crafting, building, or constructing; making, that is, instead of writing-Winterson avoids reinscribing the primacy of language. Instead, language matters when the novel points to its materiality. In examples throughout Oranges Are Not the Only Fruit, materiality overwhelms mimesis; as with the Fuzzy Felt, the true significance of Jeanette's constructions is apparent only when their fabrication remains apparent. Winterson makes it a feminist act to reinstate the "thisness" of objects, to make them "'matter' in our reading" (Ahmed, Queer 44).

Jeanette's orientation toward the material world exorcises objects of religious doctrine and resignifies them in a more open system of meaning making, which leads to feminist art. Recontextualization makes the substance of things newly visible, along with Jeanette's own materiality. That she is more artisan than author affirms Jeanette's bodily and sensuous existence. Though she is silenced in her church, she reappears as the maker of things. In the essay "Imagination and Reality," Winterson writes, "The material world is closed to those who think of it only as a commodity market," and "[t]o those people every object is inanimate. In fact they are the ones who remain unmoved, fixed rigidly within their own reality" (146). The idea that a shift in the orientation between subject and object validates the particular existences of both recalls the work of Sara Ahmed, in which object orientation affirms the existence of the (queer) subject who may otherwise be erased. Someone must be there to be oriented, producing a moment of identification for Jeanette. The implications of such a process are captured in an improbably literal way through the appearance of Winnet Stonejar, the name of one of Jeanette's fantasy avatars. Not only is this a slant or queer anagram of "Jeanette Winterson," it replaces the "son" in the author's surname with "stone," marking the character's pivot from society or family to object. Jeanette sheds her mother's ownership by sloughing off her mother's name and aligning herself with the solidity of 
things, doing so at the very moment of her exorcism, right when society becomes most threatening.

The weightiness of the name "Stonejar" is deceptive and belied by the playfulness of its adoption. Three pages before we learn Winnet's name, we read in passing that the adventuring young girl's "stone jar of food and dry clothes had been lost" (142). This small detail, easily missed, suggests that the name "Stonejar" was not planned or purposeful, keeping with Jeanette's improvisational, makeshift storytelling. ${ }^{14}$ The effect is as if narrative, attuned to the material world, snags on certain objects and pulls them into relation with the subject. A literary unconscious keeps narrative's eyes turned toward the ground, attuned to objects that typically slide past human attention, until quite suddenly, subjects and objects find themselves in new configurations that affirm their existences. The moments of exchange in which Jeanette makes and is made by objects help deflate accusations Winterson has faced about her supposed remove from feminist politics, the idea that she "creates an alternative to reality and backs off from an engagement with political and material constraints" (Pykett 60). As another young girl is told in another Winterson novel: "if you can't survive in this world, you had better make a world of your own" (Lighthousekeeping 5). Oranges Are Not the Only Fruit insists that inhabiting, resisting, or remaking relations between ourselves and the objects that surround us are political activities.

Envisioning objects as irreducible to religious or symbolic signification enables feminist art and life, but it also raises ethical and ontological questions about the nature of such things. What does it look like to move past kitsch and see objects construed as withdrawn or apart as integral to gendered interests? The elephant foot promise box, the egg-adorned watercolor Christ, and the vomit-spattered felt biblical characters emerged from a similar religious context and would seem destined, without the novel's distinctive figuring of them, to reproduce that ideology in the world. This hardwiring is true not only of Pentecostal kitsch but of the symbolic realm more

14. A style referenced by the novel's allusion to the W. B. Yeats poem "Lapis Lazuli": "All things fall and are built again / And those that build them again are gay" (30). 
broadly-of the very things that provoke hermeneutic reactions. Oranges appear over a dozen times in the novel and have received much critical attention, yet the harder one stares at the titular fruits, the less substantial they seem. Oranges derive their meaning not from Jeanette but from her overbearing mother, who substitutes fruit for affection: when a young Jeanette is in the hospital, her mother leaves her oranges $(23,25,27-28)$; when Jeanette comes home from public school feeling estranged and upset, her mother gives her an orange (40); after Jeanette is starved by her mother and congregation to exorcise her demons, she is given oranges to help her recover (114-15). Jeanette tries to engage the oranges on her own terms by playing with them as she did the felt characters, but she fails: "I tried to build an igloo out of the orange peel but it kept falling down and even when it stood up I didn't have an eskimo to put in it, so I had to invent a story about 'How Eskimo Got Eaten,' which made me even more miserable" (26). The orange peel, which cannot be a home for Jeanette any more than it is for an Eskimo, points to the hollowness of oranges in the novel and the absence at the center of Jeanette's relationship with her mother. At the end of her exorcism, the tipping point in the novel to which we keep returning, Jeanette decides of the oranges she is given: "They were pretty, but not much help. I was going to need more than an icon to get me through this one" (134). Icon is a telling word-one that brings back the image of Christ hanging in the kitchen. Icons only work if our relationships with them are fixed, their meaning prescribed by some higher authority, their circuitry closed to outside intervention. In Oranges Are Not the Only Fruit, oranges seem to glow with hidden meaning, but for the reader who, like Jeanette, looks to objects for their creative potential, these symbols quickly prove to be a dead end. Only after the luster of the oranges fades do we notice the pebble. By taking up the pebble, I demonstrate how the particular queerness of literary things inscribes their metaphysical alterity—their irreducibility, the sense they are somehow out there-which in turn allows them to advance, without being bound to, gendered interests.

The pebble first appears midway through the novel in a daydream Jeanette experiences during her exorcism, timing that insinuates its role as an alternative to the orange. As Jeanette decides to leave her 
family and start a new life, an orange-colored demon appears. He consoles her and at the end of their conversation says:

“.. . remember, you've made your choice now, there's no going back."

"What are you talking about? I haven't made any choice." I was struggling to sit up.

"Catch," called the demon and vanished. In my hand was a rough brown pebble.

The pebble resurfaces regularly, appearing in Jeanette's waking life and her fantasies. It is with her when she breaks things off with her second girlfriend: "As I left Katy behind, she was crying. I didn't know what to expect, but I knew I wouldn't live through any of that again. Hands in my pockets, I played with a rough brown pebble" (132). It is with her when she tells her congregation that she is leaving the church: "They were dumbfounded. I held on tight to the little brown pebble and hoped they'd go away. They didn't" (138). Readers have tried to make symbolic claims about the pebble: it is, variously, "the symbol of her self-integrity" (Onega 26), her "own sense of reality and selfhood" (Cosslett 26), or a "talisman" that is the "symbol of the shriveled heart of those who stay rather than embrace a life of nomadic provisionality" (Makinen 167). These accounts are unconvincing because the pebble resists partaking in the symbolic order of the novel. Though we want to ascribe it talismanic powers, the one time Jeanette asks the pebble for something magical (for her congregation to disappear), it does nothing.

What is the importance of an object that rejects our attempts to give it importance? In this respect, the pebble shares much in common with those objects of modernist literature that are "understood neither as commodity (Goods) nor as symbol (Gods), but as 'object"' (Mao 4). It has the strangely simultaneous distance and closeness to the human as the stones that Beckett's Molloy moves from one pocket to another, Virginia Woolf's array of solid objects, ${ }^{15}$ or an-

15. Winterson's debt to Woolf is significant; elsewhere she writes of Woolf: "Here she is and here she was, of private ancestors, the most complete" ("Psychometry" 131). In the context of this essay, Woolf's presence is most appreciable in Winterson's antihierarchical material world, for Woolf demonstrated "how texts as discursive environments 
other pebble that has been discussed in object-oriented literary criticism, the one in Zbigniew Herbert's "The Pebble." The poem begins: "The pebble / is a perfect creature // equal to itself / mindful of its limits // filled exactly / with a pebbly meaning // with a scent that does not remind one of anything / does not frighten anything away does not arouse desire." It ends: "Pebbles cannot be tamed / to the end they will look at us / with a calm and very clear eye" (Herbert). Herbert's and Winterson's pebbles are disconcertingly autarkic, both resist impositions of human meaning and feeling, both are immediately perceptible and tangible-Herbert's narrator holds the pebble in his hand, and both suggest that they withdraw and contain unknowable depths. Herbert's pebble marks the "selfsufficiency of the object" (Schwenger 165), and among its uses and meanings figures "the useless and the meaningless" (Frow 354). The only explicit hint the novel gives about the pebble's meaning comes at its appearance: the orange demon tosses it to Jeanette to mark the choice she has made-to turn away from her family and create the Winnet Stonejar avatar. The pebble marks her object orientation, signifying nothing but its self-sufficiency and comprehensible only through the way it turns Jeanette toward the material world.

Indifference and distance may not initially seem like politically efficacious modes, but they become precisely that for the queer protagonist constrained by an oppressive ideology that oversaturates the world around her. Different objects permit or provoke different forms of engagement or orientation, and Jeanette's relationship with the pebble suggests an alternative subject-object model than the ones offered by religious icons. Though it is sometimes in her pocket, it can hardly be said that Jeanette owns the pebble. It appears and disappears throughout the novel, forestalling the possibility of possession and thus standing against the hierarchical world in which Jeanette is raised. The most consistent use of possession in the novel is in the context of "demon-possessed," an accusation leveled at Jeanette throughout her childhood (11). A visiting pastor takes one look at her and says: "This little lily could herself be 
a house of demons" (12). Before the day-long exorcism, Jeanette's pastor cries: "These children are full of demons" (104). This threat of demonic possession is no different from the assertion that "God's in everything," because both represent a violent loss of agency that erases Jeanette's choices and desires (30). Possession first becomes a form of dispossession in Jeanette's adoption: her mother takes in the child after experiencing a divine vision which convinces her that "[s] he would get a child, train it, build it, dedicate it to the Lord" (9). In the face of this genderless, objectifying, and instrumentalist language-which represents the same evacuation of agency and substance faced by the elephant foot promise box and other religious kitsch, while concurrently allying Jeanette more closely with the object world-the pebble's tendency to withdraw thwarts claims of ownership and models antihierarchical forms of being-with.

Winterson inscribes the pebble's ability to be both available and apart in its descriptions. Every time the pebble appears, the syntactical form remains constant: it maintains the structure "[article] [adjective] brown pebble," where the article is either definite or indefinite and the first adjective is either "rough" or "little." These shifts make the pebble both solid and ephemeral. The linguistic discrepancies give it an indeterminate quality. That it is sometimes "rough" and sometimes "little" seems a product of Jeanette's experience, so the variability of her shifting perceptions becomes encoded into the literary object. This is "a" pebble, not particular, and infinitely interchangeable with other pebbles, its instability a sign of its quiddity. The pebble's linguistic shifts mirror how it appears and disappears from the narrative, how it passes back and forth between Jeanette's fantasies and reality, and how, in those fantasies, it transforms into other objects; now it is a piece of chalk, now the hardened heart of a raven. Then, suddenly, it is "the" pebble, the one that remains in Jeanette's pocket for whenever she needs it, imbued with the solidity of stone. This persistence is mirrored in the constancy of the syntactical structure and the fixity of the final two words-it is always a "brown pebble" — giving the object a persistent identity, marking the pebble as noumenon, which seems to exist through or behind language and context.

The object's doubleness is central to the novel's political strategy. By holding aloft the pebble's contingency and continuity, which is 
made possible by the literary object's discursiveness and materiality, Oranges Are Not the Only Fruit illustrates how the suspension of reconciliation between subject and object may be ethically productive. By being both fluid and solid, enduring and transitory, present and receding, the pebble complicates the Manichean worldview in which Jeanette was raised. Oranges Are Not the Only Fruit opens with a representation of her mother's understanding of reality:

She had never heard of mixed feelings. There were friends and there were enemies.

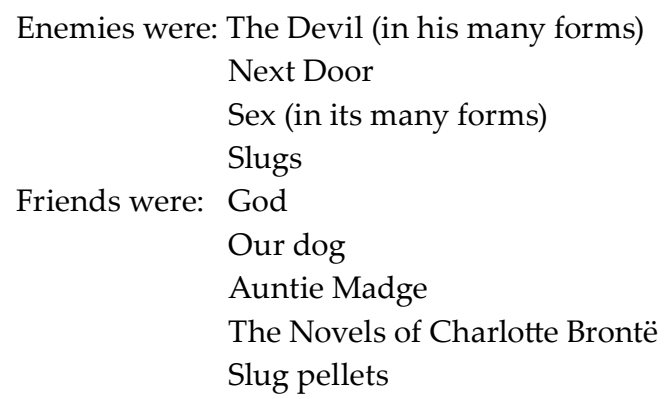

and me, at first. I had been brought in to join her in a tag match against the Rest of the World.

Just as the pebble's instability is reproduced in the text, the rigidity of Jeanette's mother's orthodoxy is enshrined in the typography. There is no room for ambiguity in the home, or in the church, or on the page. In another scene, when Jeanette is confronted by her pastor over a budding lesbian relationship, she proclaims,

"I love her."

"Then you do not love the Lord."

"Yes, I love both of them."

"You cannot."

This absolutism withers under the literary object's ability to be both, leading Jeanette into something she has never experienced: uncertainty. ${ }^{16}$ The queerness of the pebble-its ambivalence, its

16. “Uncertainty to me was like Aardvaark to other people. A curious thing I had no notion of, but recognised through secondhand illustration" (99). 
irreducibility, its illegibility, and so on ${ }^{17}$-invites Jeanette to form antihierarchical relationships with it, which then produce a more egalitarian world for her to inhabit.

The pebble promotes an open and constructive politics against the closed ideology of Jeanette's church and home, and it is one of many such objects in the novel to do so. Oranges Are Not the Only Fruit is cluttered with things that do not fit comfortably in restrictive systems of meaning making. These objects tend to share certain features: even though much of the novel takes place in a richly descriptive realist mode that details life in a mid-century working-class city in the north of England, notably few objects are branded or appear in the context of commerce. Even at its most documentary, the novel does not use objects to conjure up reality, in part because like the pebble, the objects here are the odds and ends that refuse to take part in the business of the world. The objects Jeanette lights on seem at a remove from everyday use or practice, reading like the contents of a Wunderkammer. They have little possible economic value but are filled with meaning in the eyes of the curious girl: tins of pineapple, old socks, a bit of whalebone, some geranium buds, a scrap of parchment from Lebanon, a ball of plasticine, a coin collection in a glass case that smells of linseed oil, a whelk, a piece of Tiffany glass. Even though none of these objects appear in the fantasy sections of the novel, they contribute to the fairy-tale atmosphere that colors the narrative, standing outside of a particular time or context. They often straddle the categories in which we place objects: the piece of bone is at once something from nature (when it belonged to the whale), from fashion (it comes from a cheaply made bra), and from Jeanette's imaginative life (she carries it around as a reminder not to cut corners). Taken together, these objects do not matter in spite of being valueless but precisely because of it; by passing unrecognized, they provide Jeanette respite from the world beyond. Mattering — as in being solid—allows objects, and in turn Jeanette, to exert agency over how and in what contexts they matter-as in having value to the rest of the world.

17. It is worth noting that seeing the thing as a site of relation and uncertainty rather than as plenum or fixed and tangible stuff directs us toward the origin of the word thing, in the Germanic thingan, which referred to an "appointed time for deliberation, accusation, judicial process, and decisions" (Graham 299). 
Oranges Are Not the Only Fruit takes seriously the ethical and ontological consequences of imagining objects as both substantial and withdrawn, and it does so most often through Elsie Norris, a member of the church who becomes fond of Jeanette. ${ }^{18}$ In an exchange over tea and cake, Jeanette remarks of Elsie:

She was an absolutist, and had no time for people who thought cows didn't exist unless you looked at them. Once a thing was created, it was valid for all time. Its value went not up nor down.

Perception, she said, was a fraud; had not St Paul said we see in a glass darkly, had not Wordsworth said we see by glimpses? "This piece of fruit cake"-she waved it between bites—“this cake doesn't need me to eat it to make it edible. It exists without me."

That was a bad example, but I knew what she meant. It meant that to create was a fundament, to appreciate, a supplement. Once created, the creature was separate from the creator, and needed no seconding to fully exist.

"Have some cake," she said cheerfully, but I didn't because even if Elsie was philosophically amiss, her contention that the cake existed without either of us was certainly true. There was probably a whole township in there, with values of its own, and a style of gossip.

The implied subject here is Jeanette-that she can exist without her mother and, if need be, without her god-and her art. By subordinating the receptive act to the creative one, Jeanette (both protagonist and author) immunizes her creations against outside interference. The object's alterity proves to be politically advantageous. Yet Jeanette's claim is more sweeping than that. Even if we believe that literary objects have some form of existence (and we should), we typically imagine that they "exist in virtue of certain activities of people" (Kripke 73-74). In other words, literary things only come into existence when read. But Jeanette proposes that they have a form of independent being after the act of creation, which results in a wild proliferation of objects that have being without existing-

18. It is Elsie who claims that "stories [help] you to understand the world" (28), who loves Yeats because he understood "the great effect of the imagination on the world" (30), and who believes that "If you think about something for long enough ... more than likely, that thing will happen," all claims about how fiction has material consequences in reality. 
what Meinong calls heimatlose Gegenstände, or "homeless objects" (Chisholm 207) —and suggests just how ontologically crowded the world might be. ${ }^{19}$ Because fictional objects do not need humans to maintain their being, they cannot be entirely known, and this creates an ethical crisis. Even faced with something so inert and easily consumed-by perception and degustation-as a piece of fruit cake, Jeanette cannot know with any certainty that eating it would not result in genocide. Winterson makes morally unconscionable any ontology that does not appreciate the inexhaustibility, the radical otherness of objects.

Gendered interests are distantiated from the gendered subject in Oranges Are Not the Only Fruit and are instead located in a diffuse sea of selves and things, as well as the stances they adopt toward one another. Even as new feminist materialism convincingly shows how the material world cannot be described except through the lens of the human, Winterson suggests how the human need not be the terminus of such practices and how the turn to objects does not necessitate "the 'end of feminism"' (Clare 58). Where I began by critiquing the centrality of the body-as-object in new feminist materialism and Winterson scholarship, I end by pointing to a different type of body that suggests a more constructive way forward: the corpse. Jeanette works part-time in a funeral home, which becomes her refuge when she leaves home:

I went along to help with the laying out and make up. At first I was very clumsy. I used too much rouge, and smeared it down the cheekbones.

"Show some respect," said the woman, "the dead have their pride."

We always had a check list with the burial instructions, and soon this

19. Toward the novel's end, Jeanette adds imaginary people to our already cluttered universe: "If a potter has an idea, she makes it into a pot, and it exists beyond her, in its own separate life. She uses a physical substance to display her thoughts. If I use a metaphysical substance to display my thoughts, I might be anywhere at one time, influencing a number of different things, just as the potter and her pottery can exert influence in different places. There's a chance that I'm not here at all, that all the parts of me, running along all the choices I did and didn't make, for a moment brush against each other. That I am still an evangelist in the North, as well as the person who ran away. Perhaps for a while these two selves have become confused. I have not gone forward or back in time, but across in time, to something I might have been, playing itself out" (174). 
became my particular task. I went round making sure that the dead had everything they wanted. Some just asked for a prayer book or their Bible, or their wedding ring, but some were positively Egyptian. We did photograph albums, best dresses, favourite novels, and once someone's own novel. It was about a week in a telephone box with a pair of pyjamas called Adolf Hitler. The heroine was a piece of string with a knot in it.

The dead assume a liveliness in this passage-by spending time with them, Jeanette learns that "the dead have their pride" and demand "everything they wanted" - and their vitality is tied up in objects. Here the dead are enlivened by their attachments to worldly things, evinced by the "positively Egyptian" requests of some of Jeanette's clients. This is not the living, sensual body that collapses self, text, and world into one object, but an inert body made meaningful by the affiliations it maintains toward various people and things. The corpse, like other objects, has a certain queerness about it, for if it "has now become object, it is not wholly so" (Schwenger 157), and its presence "establishes a relation between here and nowhere" (Blanchot 81). This ambivalence, and the liberating recognition that subjectivity is a story we tell, a blip in the lives of once and future objects, again remakes Jeanette's world.

In the context of the funeral home, surrounded by the dead, Jeanette flourishes. Ironically the funeral home is much more hospitable than her family home. This is where she finds refuge from her mother's autocratic rule, and once she runs away, it is where she earns the money that ensures her financial independence. The description of Jeanette's labor recalls her childhood mastery of felt and plasticine sculptures. She recounts, "I liked my work. I learned a lot about wood and flowers, and I enjoyed polishing the handles as a final touch" (60). In such a space Jeanette is able to express a gender identity that, in her home and church, left her vulnerable and subject to control. This is where she learns to apply makeup, but it is by smudging rouge on the cheeks of a dead woman rather than her own. In this context, rouge beautifies, but it also gives the corpse the appearance of vitality, so that Jeanette, in a gently grotesque way, is life-giving, and the work she does "laying out" and making sure the dead are united with their possessions reveals a nurturing self. In the funeral parlor, which is a home but not a domestic space, the 
material world cancels out the hierarchical symbolic order and enables an unfurling of gendered identity.

The flourishing enabled by the queerness of this scene-of the young lesbian surrounded by bodies that are no longer selves, in a home that is not a household-speaks to how the novel form has long represented alternative ecosystems of subjects and objects that produce more equitable futures. This is how we might understand the inclusion of the novel Jeanette buries with its author, featuring the "pyjamas called Adolf Hitler" and the "piece of string with a knot in it" for a heroine. This is a kooky version of an "it-narrative," or a "novel of circulation," a novelistic genre as old as the medium in which ordinary things - coins, cloaks, jewels, shoes, stagecoaches, and teacups-serve as central characters and narrators, commenting on human activity from positions intimately close to but distinctly apart from daily life. Not only is telling stories about the strange extension of human interests into the material world something the novel can do but, the inclusion of the it-narrative suggests, something the novel always has done.

\section{WORKS CITED}

Ahmed, Sara. Queer Phenomenology: Orientations, Objects, Others. Duke UP, 2006.

Alaimo, Stacey, and Susan Hekman. "Introduction: Emerging Models of Materiality in Feminist Theory." Material Feminisms, edited by Alaimo and Hekman, Indiana UP, 2008, pp. 1-19.

Behar, Katherine. "An Introduction to OOF." Object-Oriented Feminism, U of Minnesota P, 2016, pp. 1-36.

Blanchot, Maurice. "Two Versions of the Imaginary." The Gaze of Orpheus and Other Literary Essays, Station Hill Press, 1981, pp. 79-89.

Bogost, Ian. Alien Phenomenology, or What It's Like to Be a Thing. U of Minnesota $\mathrm{P}, 2012$.

- "Object-Oriented Feminism: At the 2010 Society for Literature Science and the Arts Conference." Blog post and comment. 5 Nov. 2010, bogost. com/writing/blog/object-oriented_feminism_1/.

Bollinger, Laurel. "Models for Female Loyalty: The Biblical Ruth in Jeanette Winterson's Oranges Are Not the Only Fruit." Tulsa Studies in Women's Literature, vol. 13, no. 2, Autumn 1994, pp. 363-80.

Bordwin, Jesse. Review of Object-Oriented Feminism, edited by Katherine Behar. Critical Inquiry, vol. 44, no. 2, Winter 2018, pp. 390-91. 
Bradway, Tyler. Queer Experimental Literature: The Affective Politics of Bad Reading. Palgrave Macmillan, 2017.

Chisholm, Roderick M. "Homeless Objects." Revue Internationale de Philosophie, vol. 27, no. 104-5 (2-3), 1973, pp. 207-23.

Clare, Stephanie. “On the Politics of 'New Feminist Materialisms."' Mattering: Feminism, Science, and Materialism, edited by Victoria Pitts-Taylor, New York UP, 2016, pp. 58-72.

Cosslett, Tess. "Intertextuality in Oranges Are Not the Only Fruit: The Bible, Mallory, and Jane Eyre." "I'm Telling You Stories": Jeanette Winterson and the Politics of Reading, edited by Helena Grice and Tim Woods, Rodopi, 1998, pp. 15-28.

Detloff, Madelyn. "Living in 'Energetic Space': Jeanette Winterson's Bodies and Pleasures." English Language Notes, vol. 45, no. 2, Fall-Winter 2007, pp. 149-60.

Felski, Rita. “Object Relations.” Contemporary Women's Writing, vol. 1, no. 1-2, Dec. 2007, pp. 185-91.

@feministkilljoy (Sara Ahmed). "And: why not wonder why the agency of the non-human has come to matter when we are dealing with the costs of human agency!" Twitter, 14 Dec. 2015, 4:07 p.m., twitter.com/SaraNAhmed/ status/676554094081941504.

- "Interesting that: the post-human seems as white as the human." Twitter, 14 Dec. 2015, 3:03 p.m., twitter.com/SaraNAhmed/status/ 676538002911399936.

Fraiman, Susan. Extreme Domesticity: A View from the Margins. Columbia UP, 2017.

Frow, John. "A Pebble, a Camera, a Man Who Turns into a Telegraph Pole." Things, edited by Bill Brown, U of Chicago P, 2004, pp. 346-61.

Gilmore, Leigh. The Limits of Autobiography: Trauma and Testimony. Cornell UP, 2001.

Graham, Mark. "Sexual Things." GLQ: A Journal of Lesbian and Gay Studies, vol. 10, no. 2, 2004, pp. 299-303.

Haraway, Donna. "Situated Knowledges: The Science Question in Feminism and the Privilege of Partial Perspective." Feminist Studies, vol. 14, no. 3, Autumn 1988, pp. 575-99.

Herbert, Zbigniew. “The Pebble.” Poems by Zbigniew Herbert, www.uvm.edu/ s sgutman/Herbert.html.

Hinton, Peta, and Iris Van der Tuin. "Feminist Matters: The Politics of New Materialism." Women, vol. 25, no. 1, 2014, pp. 1-8.

Kostkowska, Justyna. Ecocriticism and Women Writers: Environmentalist Poetic of Virginia Woolf, Jeanette Winterson, and Ali Smith. Palgrave Macmillan, 2013.

Kripke, Saul A. Reference and Existence: The John Locke Lectures. Oxford UP, 2013. Lee-Lampshire, Wendy. "Women-Animals-Machines: A Grammar for a Wittgensteinian Ecofeminism." Ecofeminism: Women, Culture, Nature, edited by Karen Warren and Nisvan Erkal, Indiana UP, 1997, pp. 412-24. 
Legler, Gretchen T. “Ecofeminist Literary Criticism.” Ecofeminism: Women, Culture, Nature, edited by Karen Warren and Nisvan Erkal. Indiana UP, 1997, pp. 227-38.

Makinen, Merja. The Novels of Jeanette Winterson. Palgrave, 2005.

Mao, Douglas. Solid Objects: Modernism and the Test of Production. Princeton UP, 1998.

Murphy, Patrick D. "Ground, Pivot, Motion: Ecofeminist Theory, Dialogics, and Literary Practice." Hypatia, vol. 6, no. 1, Spring 1991, pp. 146-61.

Olalquiaga, Celeste. Megalopolis: Contemporary Cultural Sensibilities. U of Minnesota $\mathrm{P}, 1992$.

Onega, Susana. “'I'm Telling You Stories. Trust Me': History/Storytelling in Oranges Are Not the Only Fruit." Telling Histories, edited by Onega, Rodopi, 1995, pp. 135-47.

Pitts-Taylor, Victoria. "Mattering: Feminism, Science, and Corporeal Politics." Mattering: Feminism, Science, and Materialism, edited by Pitts-Taylor, New York UP, 2016, pp. 1-20.

Pykett, Lyn. "A New Way with Words? Jeanette Winterson's Post-Modernism." "I'm Telling You Stories": Jeanette Winterson and the Politics of Reading, edited by Helena Grice and Tim Woods, Rodopi, 1998, pp. 53-60.

Schwenger, Peter. The Tears of Things: Melancholy and Physical Objects. U of Minnesota P, 2006.

Sheldon, Rebekah. “Object-Oriented Feminism: Getting Closer.” Society for Literature, Science, and the Arts Conference, Milwaukee. 27-30 Sept. 2012. Response.

Simpson, David. Situatedness: Or, Why We Keep Saying Where We're Coming From. Duke UP, 2002.

Smith, Jennifer A. "'We Shall Pass Imperceptibly through Every Barrier': Reading Jeanette Winterson's Transformative Romance." Critique: Studies in Contemporary Fiction, vol. 52, no. 4, 2011, pp. 412-33.

White, Lynn, Jr. "The Historical Roots of Our Ecologic Crisis." Science, vol. 155, no. 3767, 10 Mar. 1967, pp. 1203-7.

Winterson, Jeanette. "Art and Life." Art Objects, pp. 153-64.

- Art Objects: Essays on Ecstasy and Effrontery. Vintage International, 1995. . "Imagination and Reality." Art Objects, pp. 133-51. . Lighthousekeeping. Harcourt, 2004.

- Oranges Are Not the Only Fruit. Grove, 1985.

-. "The Psychometry of Books." Art Objects, pp. 119-32. 